\title{
THE POWER OF BROCHURE: A MULTIMODAL DISCOURSE ANALYSIS ON CHILDREN EDUCATIVE TOY "HAFIZ AND HAFIZAH TALKING DOLL"
}

\author{
Siska Eka Syafitri \\ LPDP Awardee, Doctoral Program in University of Sumatera Utara, Medan, Indonesia \\ Informatics and Technology Department, Universitas Sains Cut Nyak Dhien \\ Corresponding author: siskaekasyafitri@gmail.com
}

\begin{abstract}
Brochure as a media in promoting a product has developed by the growing of technology in this multimedia era. The inovation in brochure in fact is needed to support a success marketing. The images and words which are showed in the brochure should be present in meaningful and creative ways. It will catch the interest and raise the curiosity of the customers. Seeing the situation, studying the popular product by the brochure delivered is very important. "Hafiz and Hafizah Talking Doll" is one of the popular product in this global era. It is a kind of educative toy that is contained of many features as its superiority. This product has caught many customer and we can find so many online brochures in the internet. Therefore, analyzing the brochure of "Hafiz and Hafizah Talking Doll" is very essential. Multimodal Discourse Analysis is applied in this research to get the understanding of the brochure.
\end{abstract}

Keywords: Multimodal Discourse Analysis, "Hafiz and Hafizah Talking Doll" Brochure, Marketing a product.

\section{Introduction}

Nowadays, many messages delivered creatively in many visual media. It comes along with the information which is running fast all the time and demanding more attrative media to the readers. Reading the visual media becomes very important to catch the advantages or knowledge in. Seing this condition, today, many products are promoted by visual advertisements. We can find millions in the internet the brochures that offers so many commercial products.

"Hafiz and Hafizah Talking Doll" is one of the best seller product. This kind of educative toys has track the record because of the increasing of demand by customers toward the product. The brochures is scattered in the internet and always be renewing with an update kind of offers. Tiga Raksa is the producer of this Indonesian product with the slogan "Solusi Pintar untuk Menghafal Al Qur'an" (Smart Solution to Memorize Al Qur'an). It is a kind of effort to introduce the islamic children with Al Qur'an and to facilitate them within the interesting features. Besides, the cash and credit payment is available. These important reasons then make the brochures to have a deep analysis. 
Multimodal discourse analysis has enrich the linguistics study with many researches. Some of them are focussing on Picture Books (Wu, 2014), Movie (Cheng \& Liu, 2014), Magazine Covers (Behshad \& Ghaniabadi, 2015), Tmall's Advertisement (Hu \& Luo, 2016) Advertisements (Guo \& Feng, 2017), and Cartoon (Ariyo \& Samuel, 2017). The analysis based on the commercial products are still limited. by doing the analysis of multimodal on children educative toys "Hafiz and Hafizah Talking Doll" hopefully it will contribute to the linguistics study.

\section{Literature Review}

Many images are served in much media. Each images have their own meaning which some of the texts are written explicitly on the picture. On the contrary, the images also have their own meanings even the word are silent in their text forms. Pictures, or image texts as a more scientifically term we can now use, are often thought of being worth a thousand words (Hermawan, 2011). It is important to build the meaning whether written or not. Because the images usually deliver the meaning without depend on the text. Therefore, the understanding of grammar as a visual design are proposed to understand the images on the media. As Halliday (in Kress \& Leeuwen, 2006: 2) stated:

"Grammar goes beyond formal rules of correctness. It is a means of representing patterns of experience... It enables human beings to build a mental picture of reality, to make sense of their experience of what goes on around them and inside them."

Since the language as a sign of communication, it is also important to discuss about images as a sign in semiotics form. Reading images is essential $t$ understand the semiotics mode rewith any signifiers in. Which the forms are used to realized meaning According to Kress \& Leeuwen sign-making is realized in many signifiers such as colour,perspective and line.

The grammar of visual design by kress \& leeuwen (stated in Unsworth, 2008) adopted from Halliday's theory of Systemic Functional Language (SFL) are Representational /ideational (strucctures verbally and visually construct the nature of events, the objects and participants involved, and the circumstances in which they occur); Interactive/interpersonal (verbal and visual resurces construct the nature of relationships among speakers/listeners, writers/readers, and viewers and what is viewed); and Compositional/textual (meanings are concerned with the distribution of the information value or relative emphasis among elements of the text and image).

Liu (2013) stated that multimodal discourse analysis is analyzing how several or all of the different semiotic modes go together to create a unified text or communicative event. In this case critical analysis is needed. By this situation the approach of multimodal discourse analysis is appropriate tobe applied in conducting the research of "Hafiz and Hafizah Talking Doll" brochures in identifying the meaning textually and semiotically. 
Proceedings of the $1^{\text {st }}$ Annual International Conference on Language and Literature, 18-19 April 2018, Fakultas Sastra, UISU, Medan, Indonesia.

\section{Research Method}

In this research, there are ten brochures tobe analyzed to get the better analysis on the approach of Multimodal Discourse. The brochures may be differ on each strategies in promoting the "Hafiz and Hafizah Talking Doll". The research is conducted in qualitative in the linguistic framework. It is done by applying the SFL to the identification of the meaning. Therefore, it could build our persfective in understanding reading images as well as inspire us in gathering consumers by visual media.

\section{Discussion}

Using the mulltiomodal discourse analysis with SFL, the brochures are divided into these three categories in meaning, representational/ideational, interactive/ interpersonal, and compositional/textual.

\section{Representational/ideational}

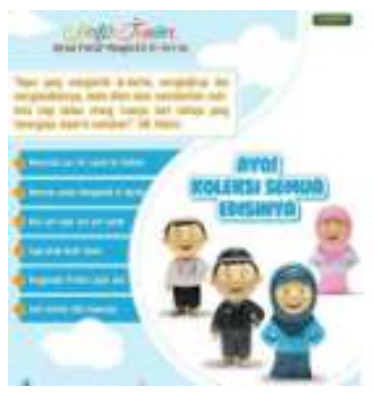

Picture 1

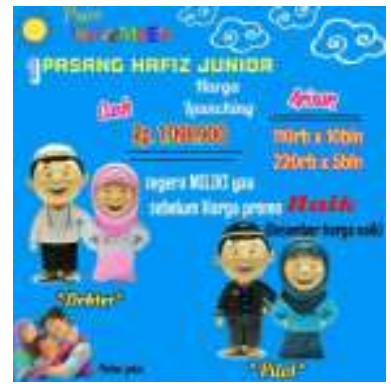

Picture 2

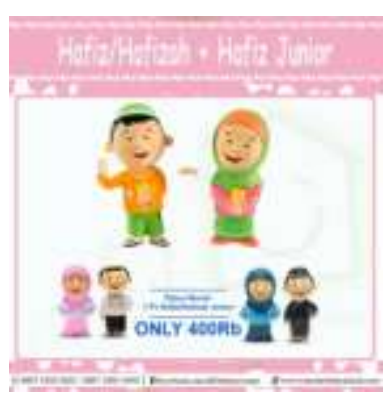

Picture 3

Verbally by these three brochures, it can be analyzed some of the clauses:

Picture 1

"Siapa yang menghafal Al Qur'an, mengkajinya dan mengamalkannya, maka Allah akan memberikan mahkota bagi kedua orangtuanya dari cahaya yang terangnya seperti matahari." (H.R. Hakim)

This clauses is the hadist from the prophet Rasulullah SAW. If we analyze this clause, there is one dominant process here, it is, material process.

\begin{tabular}{|l|l|l|l|c|}
\hline Siapa & yang menghafal & mengkaji & mengamalkan & Al Qur'an \\
\hline Everybody & who is memorizing & studying & applying & Al Qur'an \\
\hline \multirow{2}{*}{ Actor } & \multicolumn{3}{|c|}{ Process } & Goal \\
\cline { 2 - 5 } & mental & material & material & \\
\hline
\end{tabular}

\begin{tabular}{|l|l|l|l|l|}
\hline Allah & Akan memberikan & mahkota & $\begin{array}{l}\text { bagi kedua } \\
\text { orangtuanya }\end{array}$ & $\begin{array}{l}\text { dari cahaya yang terangnya } \\
\text { seperti matahari }\end{array}$ \\
\hline Allah & will give & crown & for his/her parents & from a sunny glow \\
\hline Actor & Material process & Goal & Recipient & Quality Circumstance \\
\hline
\end{tabular}

Picture 2

Segera miliki ya (hafiz junior) sebelum harga promo naik. 
The second picture also contain of material process by looking at the verb that is doing the activity (Sinar, 2010: 32).

\begin{tabular}{|l|l|}
\hline Segera miliki & Ya (Hafiz junior) \\
\hline Purchased & It (Hafiz junior) \\
\hline Material process & Goal \\
\hline
\end{tabular}

\begin{tabular}{|l|l|l|}
\hline Sebelum & Harga promo & Naik \\
\hline Before & The Promo price & Getting rise \\
\hline Time circumstance & Client & Material process \\
\hline
\end{tabular}

Picture 3

Tebus murah 1 piece hafiz/hafizah junior only 400rb.

\begin{tabular}{|l|l|l|}
\hline Tebus murah & 1 piece hafiz/hafizah junior & only 400rb \\
\hline Inexpensive pay & 1 piece hafiz/hafizah junior & only 400rb \\
\hline Material process & Goal & Attribute \\
\hline
\end{tabular}

This third picture also show the material process which is show and serve for the customers and readers.

Visually, The brochures, beside are written verbally, they are also explicitly offer the reader that it will give the advabtages for the customers to get the product. Explicitly, the producer say to "Purchase" all the items in pairs or pieces. We can see it by the various features, colours, and professions of the hafizh doll. In fact, "purchase" also show the "material process".

In the text also even it is not written, we can read that the images show the main participant of the brochure is the doll, hafiz and hafizah and also hafiz junior. These all images in the picture are readily smile and say hello to the readers as the "candidate" of customers. With the attractive colourful doll, afcourse will give the nice "eye catching" especially for the children.

\section{Interactive/interpersonal}

In this brochures we can also looking at the relationship among viewers and what is viewed (Kress \& Leeuwen in Unsworth, 2008).

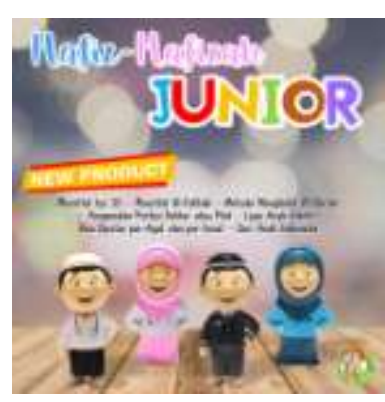

Picture 4

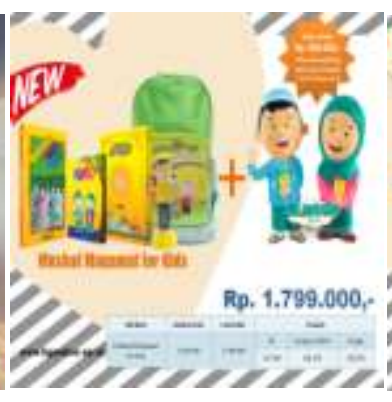

Picture 5

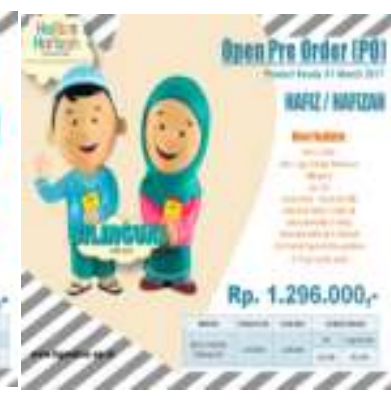

Picture 6

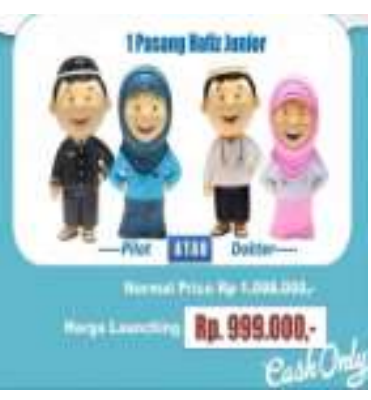

Picture 7

Interpersonally the whole of this forth brochures is showing the relationship between producer and customer of a product. In this case, the producer is "Tiga Raksa" we can 
see the website addres, www.tigaraksa-ep.id. Then, the customers is the reader of the brochures including the person purchasing the products. At last the product is the educative toy, "Hafiz and Hafizah Talking Doll".

We can also see the different offers and promotions, from the producer to the customers, in each brochures. In picture 4 it is showed that it offer a "New Product", hafiz/hafizah junior in two kinds of profession, they are doctor and pilot. This two cool profession show the importance of studying Al Qur'an even they are full of agenda with their business in hospital and aeroplane.

Then, in picture 5 it is showed that the new offer for the customers is, if the customers buy the "Mushaf Maqamat for Kids" they could get hafiz/hafizah as well. Of course with the regularities o the producer. One of the interesting point in this brochure is, the producer also offer a cash and credit payment. It show that it is not totally hard to having this product.

In picture 6 it is shown that the produt is deliver in new features and bilingual edition, this upcoming product will ready at a certain date and need to be "pre-order". "PreOrder" (PO) is the example of communication between producer and customers, in this case tiga raksa and the readers.

Same with the previous picture, the producer are offering the customers a new product, hafiz/hafizah junior, a "speciall price" are offering to get more customers.

\section{Compositional/textual}

Todays brochures, however, sometimes do not put so many information verbally in. The picture and a keyword ca presented what is mainly porposing by the brochure. We can see the examples in these belowing pictures:

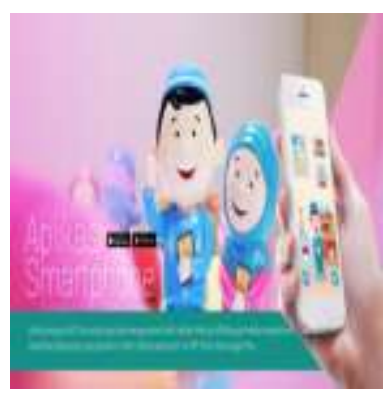

Picture 8

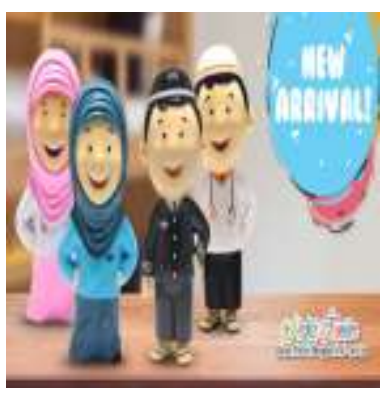

Picture 9

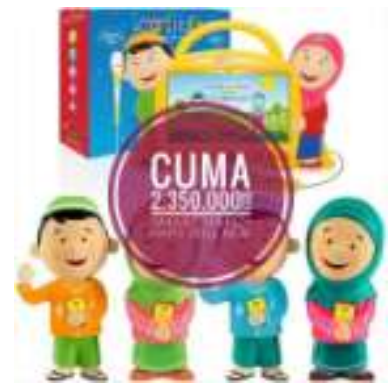

Picture 10

In interpreting the brochures, textually we should understand what is given as a theme and what is new as the rheme of the information. These three brochures, entirely show the theme in a simple quotation.

The difference on each brochures, the Picture 8 theme is "Ready on Smartphone Aplication", the theme of Picture 9 "New Arrival Product of Tiga Raksa", and the last, picture 10 theme's "Special Price, Rp 2.350.000". These II themes will easily understand by the readers of te brochures, even there are not flowery explanation 
about that. Ofcourse, the theme take the curiosity of the customers and readers, whether asking or buy the products. While the rheme is the product, hafiz/hafizah doll, the educative toy.

\section{Conclusions}

Understanding the brochures of "Hafiz and Hafizah Talking Doll" by applying Multimodal Discourse Analysis (MDA) is very interesting and important for getting the knowledge about making a brochure especially for commercial aspect. The analysis showed that the brochures are design textually and visually to represent the material process about the product including the importance, price and service of the product. The colourful and facial expression of the product is attracting the customers for purchasing one, some, or the whole products. Besides, the interactive communication of the producer to the customers are build by showing the new product, pre-order and speccial price. One of the essential one is the producer offer the customers to buy the product in cash or credit payment. The latter payment shows that the producer try to make a close relationship to the customers by having the product easily. Because today, is multimedia era and someone can get information as fast as possible in the internet, sometimes the brochures is served not fully in words but only in a phrase. It is because the picture has deliver information for the readers and understanding what is given emphasis of the picture is the key in reading images. The good brochures ofcourse will supporting an increasing advantages of a product for example the "Hafiz and Hafizah Talking Doll" as a best seller products. The futher research about MDA especially in colouring and space of the brochure will enrich this kind of study.

\section{References}

Ariyo. and Kayode Samuel. (2017). Satirizing the Nigerian Climate: Multimodal Discourse Analysis of Selected Political Cartoons from TELL Newsmagazine. Asian Research Journal of Arts \& Social Sciences , 3(4), 1-10

Behshad, Azam. and Saeed Ghaniabadi. (2015). Visual Analysis of Magazine Cover. Linguistics, 7(5), 20-32

Guo, Fang. and Xiaowen Feng. (2017). A Multimodal Discourse Analysis of Advertisements-Based on Visual Grammar. Arts and Humanities. 6(3), 59-69

Hermawan, Budi. (2011). Reading Images: The Grammar of Visual Design by Gunther Kress and Theo Van Leeuwen Second Edition. (Book Review). Conaplin. 1(1), 147-148

Kress, G.R. and Van Leeuwen, T. (2006). Reading Images: The Grammar of Visual Design. London: Routledge.

Kress, G.R. and Van Leeuwen, T. (2010). Multimodal Discourse: The Modes and Media of Contemporary Communication. London: Bloomsbury

Liu, Jing. (2013). Visual Images Interpretive Strategies in Multimodal Texts. Language Teaching and Reseach, 4(6), 1259-1263

Liu, Wenyu. and Yonghong Cheng. (2014). A Multimodal Disourse Analysis of the Relationship between $\mathrm{Pi}$ and Richard the Tiger in the Movie Life of Pi. Language and Literature, 2(4), 193-219

Luo, Mengxi. And Chunyu Hu. (2016). A Multimodal Discourse Analysis of Tmall's Double Eleven Advertisement. English Language Teaching, 9(8), 156-169. 
Proceedings of the $1^{\text {st }}$ Annual International Conference on Language and Literature, 18-19 April 2018, Fakultas Sastra, UISU, Medan, Indonesia.

Sinar, T. Silvana. (2010). Teori dn Analisis Wacana: Pendekatan Linguistik Sistemik Fungsional. Medan: Pustaka Bngsa Press

Unsworth, Len. (2008). Multimodal Semiotic Analysis and Education. Multimodal Semiotics (pp. 1-13). London: Continuum

Wu, Shuxuan. (2014). A Multimodal Analysis of Image-Text Relations in Picture Books. Theory and Pratice in Language Studies 4(7), 1415-1420 